sciendo Порівняльна професійна педагогіка 9(3)/2019 Comparative Professional Pedagogy 9(3)/2019

DOI: $10.2478 / \mathrm{rpp}-2019-0025$

PhD in Pedagogical Sciences, Associate Professor, OLENA MARTYNYUK

Khmelnytskyi National University

Address: 11 Instytutska St., Khmelnytskyi, 29016, Ukraine

E-mail: helena.martynyuk@gmail.com

\title{
AMERICAN FLIPPED CLASSROOM MODEL IN TEACHING LINGUISTIC DISCIPLINES TO STUDENTS MAJORING IN A FOREIGN LANGUAGE
}

\begin{abstract}
The paper deals with the technology of using a flipped classroom model in teaching linguistic disciplines to students majoring in a foreign language. The suggested idea of 'flipped classroom' is based on the use of Moodle learning platform which is designed to provide educators and learners with a secure and integrated system to create personalised learning environments. The efficiency of flipped classroom model has to be ensured by incorporating in practice the so-called four pillars of flipped learning defined by the Flipped Learning Network community as flexible environment, learning culture, intentional content, and professional educator. The procedure of flipping a classroom can be efficiently arranged taking into account a step-by-step guide provided by the University of Texas at Austin: identifying in what part of the course the flipped classroom model may be used most efficiently; spending class time engaging students in application activities with feedback (peer instruction, team-based learning, case-based learning, processoriented guided inquiry learning); clarifying links between in-class and out-of-class learning; adapting learning materials for students to acquire course content in preparation of class; extending out-of-class learning by means of individual and collaborative tasks. The recommendations for in-class language learning activities using the Extempore app in flipping the classroom have been considered. The conclusion has been made about the main advantages and challenges of the flipped classroom model in teaching a foreign language.

Keywords: flipped classroom, linguistic disciplines, foreign language learning, Moddle learning platform, Extempore app, peer instruction, team-based learning, casebased learning, problem-based learning, collaborative practice.
\end{abstract}

\section{АНОТАЦІЯ}

У статті розглянуто технологію використання перевернутої моделі навчання під час вивчення лінгвістичних дисщиплін студентами, для яких іноземна мова $\epsilon$ фаховою. Запропонована ідея «перевернутого навчання» базується на використанні навчальної платформи Мооде, створеної з метою надання викладачам та студентам надійної, безпечної та інтегрованої системи для створення персоналізованих навчальних середовищ. Ефективність перевернутої моделі навчання має бути гарантована використанням на практиці чотирьох принципів перевернутого навчання, визначених спільнотою Мережі перевернутого навчання (Flipped Learning Network), a caме: гнучкого навчального середовища, інноваційної навчальної моделі, свідомого підходу до організачії змісту навчання та кваліфікованого педагога. Процес перевернутого навчання можна ефективно організувати, враховуючи покрокові інструкції, надані Техаським університетом в Остіні: визначення місия, де перевернута модель навчання має найбільший сенс для вивчення дисцииліни; використання аудиторного часу для залучення 
студентів до навчальної діяльності із забезпеченням зворотнього зв'язку від викладача (навчання однолітків, навчання в команді, навчання на основі конкретних випадків, орієнтоване на процес навчання); встановлення зв'язків між аудиторним та позааудиторним навчанням; адаптація навчальних матеріалів для студентів для ефективного засвоєння змісту дисципліни під час підготовки до заняття; варіативність форм позааудиторного навчання, наявність індивідуальних та групових завдань. Розглянуто рекомендації щзодо видів англомовної навчальної діяльності на заняттях із застосуванням програмного додатку Extетроге для перевернутого навчання іншомовного спілкування. Зроблено висновок про основні переваги та недоліки перевернутої моделі навчання під час викладання іноземної мови.

Ключові слова: перевернуте навчання, лінгвістичні дисципліни, вивчення іноземних мов, платформа для навчання Moddle, програмний додаток Extетроте, навчання однолітків, командне навчання, навчання на основі конкретних випадків, проблемне навчання, коопероване навчання.

\section{INTRODUCTION}

Rapid development of information and communication technologies provides the opportunity to increase the efficiency of higher education, to reduce the share of traditional classroom-based forms of teaching (lectures, seminars, etc.) and to encourage students' independent learning by shifting the focus from the teacher-to-students knowledge transfer to the students' knowledge construction supported and guided by a teacher. Currently, the higher education system is integrating educational technologies within the competence paradigm. An effective means of its implementation is the so-called 'flipped classroom' - a model which is sometimes defined as 'inverted classroom' (Lage, Platt, \& Treglia, 2000; Talbert, 2012) or 'flipped learning' (Bergmann \& Sams, 2012; HEA, 2018).

Learning their subjects in the traditional way, students acquire knowledge in the classroom. After classes they simply analyse, summarize and evaluate the information. On the contrary, flipped learning is a pedagogical technique according to which the usual process of in-class learning is inverted. Hence, students study the material before attending classes and at classes they try to get deeper understanding of the topics by discussing them with their groupmates and performing problem-solving activities that are encouraged and monitored by teachers. After classes, students are involved in the reflection upon the feedback they were provided in order to use it to extend their learning (HEA, 2018).

\section{THE AIM OF THE STUDY}

The aim of this paper is to consider how to use a flipped classroom model in teaching linguistic disciplines to students majoring in a foreign language.

\section{THEORETICAL FRAMEWORK AND RESEARCH METHODS}

The concept of 'inverted classroom' was firstly used by Professors of Economics from Miami University (Ohio) to explain the use of their technique (Lage, Platt, \& Treglia, 2000).

The term 'flipped learning' began to be widely used in the early middle of 2000s. At that time it was promoted by J. Bergman and A. Sams, who became co-founders of the Flipped Learning Network (Bergmann, \& Sams, 2012) and S. Khan, who founded the Khan Academy (TED, 2011). But the notion of flipped learning dates back to much earlier times (Talbert, 2012).

In the 1990s, E. Mazur from Harvard University developed a 'peer instruction' model according to which he initially provided learning materials for students to study before class and then, in class, he challenged them and encouraged to profound cognitive thinking while they were interacting (Crouch, \& Mazur, 2001). 
Sciendo Порівняльна професійна педагогіка 9(3)/2019 Comparative Professional Pedagogy 9(3)/2019

This model was further expanded and the other technological procedures were included. The 'flip' concept was developed and the teacher was assigned the role of a facilitator and a coach. Further research concentrated upon the concept of 'inverting the classroom' to ensure an inclusive learning environment where individual coaching and mentoring was a regular teaching activity (Lage, Platt, \& Treglia, 2000).

From that time to the present days, extensive development of online resources and professional networks encourage cooperation among teachers and supply them with accessible tools for practising flipped learning. Creation of software such as Screenr and Webinaria as well as distribution tools such as Youtube and Vimeo give the possibility to effortlessly develop content for flipped learning. Moreover, there is a great number of media to be re-used, namely iTunesU, Open Yale Courses and Khan Academy) (HEA, 2018).

Flipped learning has not been extensively referred to as an independent pedagogical approach in higher education. But still there are many cases showing considerable improvements in motivation among students and teachers, increased class attendance, and better grades which have been the consequence of applying the flipped learning approach (Hamdan et al., 2013).

In 2011, considerable progress in test scores was observed after flipping a part of a large enrollment class studying Physics at Vanderbilt University (the USA) (DesLauriers, Schelew, \& Wieman, 2011). In 2012-2013, the staff of the University of Queensland (Australia) succeeded in implementing a large-scale flipped learning project involving more than 1,000 students and integrating a wide range of disciplines. This university is currently one of the leaders in global university partnership aimed at initiating better understanding how education process might be reconstructed involving a flipped learning model and how expansion and adoption of progressive educational experience in the field of flipped learning could be developed (University of Queensland, 2014).

The Schools of Social Sciences and Computer Science at the University of Manchester (the UK) conducted an experiment in which they flipped the tutorial by supplying a video for the students to watch before the tutorial and then used the tutorial time for working in small groups. The activities were organized within the problem-based learning approach. Reflection upon the experiment testifies to general improvement in student participation and defines the problems in implementing small group work within larger groups of students (University of Manchester, 2014).

American colleges and universities were the first to adopt the flipped learning model. This concept has been supported in the UK as well. Thus, flipped classroom as an innovative learning technology has a significant impact on higher education abroad and it is being introduced into the education process in Ukraine as well.

On using a set of theoretical research methods such as analysis, synthesis, interpretation, comparison and generalization of foreign pedagogical experience as well as empirical research methods, namely observation, interviewing, testing and rating students' progress, we suggest an idea of applying a flipped classroom model in teaching linguistic disciplines to students majoring in a foreign language.

\section{RESULTS}

Considering the information provided by the Flipped Learning Network (FLN, 2014), we believe that the terms 'flipped classroom' and 'flipped learning' cannot be interchanged. Flipping a class might not involve flipped learning. Sometimes teachers flip their classes by making students read subject-related texts or watch supplementary videomaterials out-of-class, engaging them in problem-solving activities, etc. But the 
concept of flipped learning assumes that teachers have to incorporate into their practice the so-called four pillars of flipped learning which are described as follows (FLN, 2014):

Flexible environment. Flipped learning may include numerous learning approaches. Teachers often re-schedule learning activities to allocate a lesson or a unit, to encourage either group or students' individual work. They accommodate flexible spaces and students are to decide when and where they will study. Moreover, while flipping their classes, teachers are flexible in setting the timeline for students' learning and in assessing students' progress.

Learning culture. Within the conventional teacher-centered approach, a teacher is the key source of knowledge. On the contrary, the flipped learning model is more learner-centered. Inclass time is dedicated to acquiring expertise in the topics. Hence, students are provided with greater learning possibilities. They are more interested in the process of knowledge construction while taking part and evaluating their progress in the most appropriate way.

Intentional content. Teachers who implement the flipped learning model always consider the ways of using it to facilitate students' understanding of conceptual and procedural fluency. They decide upon the materials they have to teach as well as the topics for students' own research. Teachers apply intentional content to increase time for classroom activities and to adopt student-centered, active learning strategies that depend on the level of knowledge and subject matter.

Professional educator. In a flipped classroom, the importance of a professional educator is great. It is even more demanding than in a conventional classroom. Teachers always have to observe their students, provide them with the relevant feedback and evaluate their progress. Professional educators communicate with other colleagues to exchange and advance their teaching strategies, engage in constructive criticism and learn how to avoid chaos in their classrooms. Professional educators remain the integral part of the flipped learning environment.

The idea of 'flipped classroom' in Khmelnytskyi National University (Ukraine) is based on the use of Moodle learning platform which has been designed to enable teachers, administrators and learners to use a secure and integrated system for creating personalized learning environments. Moodle offers a number of ways to import, export and manage digital content aimed at supporting flipped learning. After creating a course in Moodle environment teachers (in our case foreign language teachers) don't need to focus mainly on conveying information (e. g. lecturing), giving homework, and leaving it to students to study the material individually. They often add electronic resources (e.g. video and audiorecordings, links to videolessons from free educational websites, new vocabulary lists, grammar explanations, pronunciation guides, lecture materials, other tasks and activities) for students to view and complete at home before the next class. This provides in-class time to exchange knowledge and master the material employing collaborative learning, preparing projects and organizing discussions.

We are convinced that the procedure of flipping a classroom can be efficiently arranged taking into account a step-by-step guide provided by the University of Texas at Austin, USA (2019):

1. Identifying in what part of the course the flipped classroom model may be used most efficiently.

2. Spending in-class time involving students in application activities and ensuring feedback.

There are various evidence-based teaching approaches that create engaging class environments. The following are the main approaches to students' collaboration and problem solving used at the University of Texas: 
Sciendo Порівняльна професійна педагогіка 9(3)/2019 Comparative Professional Pedagogy 9(3)/2019

Peer Instruction. After preparing for classes, students provide teachers with the relevant feedback about the problems they encountered. In class, students listen to minilectures combined with peer discussions of key points that help elicit, confront, and resolve misunderstandings students may have.

Team-based Learning. After preparing for classes, students have a content-based readiness-assurance quiz at the beginning of class (first as individuals and then as a team). Teams immediately receive feedback on their performance while teachers fill in the gaps in understanding by mini-lectures. Then, teams take part in structured application activities intended to make the necessary choice simultaneously.

Case-based Learning. Students cooperate in small groups with an instructor's supervision to detect problems and assess students' attempts to solve them.

Process-oriented Guided Inquiry Learning. Learning activities are arranged in such a way that students research data or information indicated by questions, make up their own conclusions, and use the acquired concepts in further learning. The activities are organized to develop procedure skills, critical thinking, problem solving abilities and collaboration techniques.

3. Clarifying links between in-class and out-of-class learning. The goal of the flipped learning model is to replace in-class lecturing by application-oriented home tasks and to have students study lecture materials before class. Further activities may involve finishing the work started in class or reading additional materials on the topic as well as a larger group assignment.

4. Adapting information for students to understand the course content while getting ready for classes. The dynamic learning environment is an essential condition of the flipped classroom. That is why students have to come prepared for class. It is crucial for students to be responsible enough to complete their pre-class assignment, and be provided with an opportunity to ask questions about the content they are learning out-of-class.

5. Extending out-of-class learning by means of individual and collaborative tasks. It may be helpful here to use message boards or academic social media to develop the ideas expressed in-class, introduce relevant problems, give assignments that make students apply skills and knowledge acquired in class in a new situation which has not been discussed in class, assign supplementary readings relevant to the concepts considered in class, motivate students to create new learning groups, etc.

The flipped classroom model of teaching linguistic disciplines may be further developed considering the recommendations provided by the Flipped Learning Network (2019) on how to use Extempore app in flipping the classroom for language instruction. Extempore is the platform designed for teachers of foreign languages. It enables them to evaluate authentic speech without organizing face-to-face communication with their students. Teachers can create various assignments using the Extempore website. Students can access these activities via their device or computer. On both platforms, learners can choose to submit answers through either video or audio. Teachers are able to grade the submitted answers and remotely provide written or oral feedback from their mobile or desktop device (Extempore app website, 2019).

K. Walsh (2016) suggests using Extempore for the development of students' foreign language speaking competence by initially recording a brief demonstration of a new vocabulary or grammar topic to be covered. Next, students have to complete simple comprehension questions in the target language testing their ability to absorb and produce this new information in limited contexts. It may involve: 
- modelling standard pronunciation for students, asking them to submit their own attempts via the Extempore app. and providing them with the relevant feedback to facilitate improvement;

- asking either simple yes or no (true or false) or basic comprehension questions referring to a vocabulary list, considering relevant images, etc. After that students submit their responses before the next class;

- encouraging students to create a video journal as a type of self-reflective activity. Students can use them to comment on the lesson and ask questions that they may still have about the content.

Flipping course instruction allows students to absorb the material as fast as they can. Combining this with formative assessments it's possible to encourage students to actively engage in the target language by practicing what they have just learned. It helps them maintain a regular habit of speaking outside of the classroom where it could be lacking (Walsh, 2019).

\section{CONCLUSIONS}

Taking into account the results of research in this field we can conclude that flipped classroom is an efficient model in teaching linguistic disciplines to students majoring in a foreign language. In a flipped classroom, students are able to control their own learning and learn as fast as they can. Students are free to pause or rewind the videomaterials, put down a list of questions, and discuss the material with their teachers and groupmates in class. Flipped classroom allows using in-class time to acquire skills participating in collaborative projects and group discussions. This motivates students to teach each other and learn key points cooperatively with the support of their teachers. Moreover, teachers have the possibility to identify mistakes in understanding or concept application. A flipped classroom model can be rather efficient in foreign language learning due to its focus on target language use in classroom while students are working on interactive activities. Scaffolding as well as peer-teaching may frequently be more efficient for some students than conventional teaching approaches. In-class activities may seem more real-life when there is enough time for them. By having the learning materials available online, students who missed classes because of illness, participation in sporting events, or facing emergencies, can catch up with the group quickly. It also ensures more flexibility for teachers.

Still, it's necessary to mention several challenges of the flipped classroom model. One of the most significant points here is the need for students to have access to a computer and Internet to explore the learning materials. Since flipped classroom depends on students' involvement, it's impossible to guarantee that they will cooperate with instructors within the flipped model. Furthermore, applying a flipped classroom entails excessive workload on teachers. Their responsibilities consist in providing videolectures and uploading other learning materials (which is a painstaking and time-consuming job), and practicing motivating in-class activities that will make students actively participate and prepare for class. Flipped classroom is not the model of teaching aimed at improving standardized test scores. However, students and teachers still need to spend a considerable part of time getting ready for state mandated testing, which, in its turn, may interrupt the flipped classroom process.

Perspectives for further studies include evaluation of students' progress in a flipped classroom, approaches to encourage students' motivation to actively participate in the flipped learning activities, development of online tools and apps for implementing a flipped classroom model in foreign language teaching. 
sciendo Порівняльна професійна педагогіка 9(3)/2019

Comparative Professional Pedagogy 9(3)/2019

\section{REFERENCES}

1. Bergmann, J., \& Sams, A. (2012). Flip Your Classroom: Reach Every Student in Every Class Every Day. Washington, DC: International Society for Technology in Education.

2. Crouch, C.H., \& Mazur, E. (2001). Peer Instruction: Ten Years of Experience and Results. American Journal of Physics, 69, 970-977.

3. DesLauriers, L., Schelew, E., \& Wieman, C. (2011). Improved Learning in a Large-Enrollment Physics Class. Science, 332, 862-864.

4. Extempore app website. (2019). Why extempore. Retrieved from https:// extemporeapp.com/.

5. Flipped Learning Network. (2014). The Four Pillars of F-L-I-PTM. Retrieved from https://flippedlearning.org/wp-content/uploads/2016/07/FLIP_handout_FNL_Web.pdf.

6. Hamdan, N., McKnight, P., McKnight, K., \& Arfstrom, K. (2013). A Review of Flipped Learning. Retrieved from https://flippedlearning.org/wp-content/uploads/2016/07/ LitReview_FlippedLearning.pdf.

7. Higher Education Academy. (2018). Flipped Learning. Retrieved from https://www.heacademy.ac.uk/knowledge-hub/flipped-learning-0.

8. Khan, S. (2011). Let's Use Video to Reinvent Education. TED. Retrieved from https://www.ted.com/talks/salman_khan_let_s_use_video_to_reinvent education.

9. Lage, M.J., Platt, G.J., \& Treglia, M. (2000). Inverting the Classroom: A Gateway to Creating an Inclusive Learning Environment. The Journal of Economic Education, 31, 30-43.

10. Talbert, R. (2012). Inverted Classroom. Colleagues, 9 (1). Retrieved from http://scholarworks.gvsu.edu/colleagues/vol9/iss1/7.

11. The University of Manchester. (2015). Flipping the Classroom. Retrieved from http://www.elearning.eps.manchester.ac.uk/blog/2014/flip/.

12. The University of Queensland. (2012-2017). Flipped Classroom Project (OLT). Retrieved from http://www.uq.edu.au/tediteach/flipped-classroom/olt-transforming/ index.html.

13. The University of Texas at Austin. (2019). How do you flip a class? Retrieved from https://facultyinnovate.utexas.edu/how-to-flip.

14. Walsh, K. (2019). Flipping the language classroom. Retrieved from https://flippedlearning.org/academic_subject/foreign_languages/flipping-the-languageclassroom/ 